\title{
EKSISTENSI HUKUM WARIS DI INDONESIA: ANTARA ADAT DAN SYARIAT
}

\author{
Komari \\ Mahkamah Agung Republik Indonesia \\ Email:komari@yahoo.com
}

\begin{abstract}
This paper explains about the application of inheritance law in Indonesia which is strongly influenced by three law systems such as Islamic law, customary law, and Western law. At the beginning of Islam in Indonesia, Islamic law is very dominant in the implementation of Islamic inheritance law which is intergrated with culture and tradition among Muslim society. In Colonial period, the government of Dutch East Hindia started to establish Western law for European and East Asian people. But for the Muslim citizens in Indonesia was implementting the combination of Islamic law and customary law. In the independence period, the political of law has been changed through unification and codification of Islamic law into the Indonesia rules formally, including in the application of Islamic inheritance law. As long as this policy, Islamic inheritance law in Indonesia has a characteristic of the combination between Islamic law and customary law.
\end{abstract}

\begin{abstract}
Abstrak
Tulisan ini menjelaskan tentang pelaksanaan hukum waris di Indonesia yang sangat dipengaruhi oleh tiga sistem hukum, yaitu hukum Islam, hukum Adat, dan hukum Barat. Pada masa awal kedatangan Islam di Indonesia, hukum Islam sangat mendominasi pelaksanaan hukum waris yang berkelindan dengan Adat istiAdat dan budaya masyarakat muslim. Memasuki masa penjajahan, Pemerintah Kolonial Hindia Belanda mulai menerapkan kebijakan hukum Barat bagi bangsa Eropa dan Timur Asing. Sedangkan bagi pribumi diberlakukan kombinasi hukum Islam dan hukum Adat. Memasuki fase kemerdekaan, politik hukum berubah seiring dengan kebijakan kodifikasi dan unifikasi hukum dengan cara memasukan hukum Islam ke dalam sistem hukum positif di Indonesia, termasuk dalam hal pemberlakuan hukum waris. Namun yang tampak saat ini adalah pelaksanaan hukum waris di Indonesia lebih bercirikan kombinasi antara Adat dan syariat.
\end{abstract}

Kata Kunci:

Hukum Islam, Hukum Adat, Hukum Barat, Hukum Waris, Kodifikasi

\section{A. Pendahuluan}

Hukum Adat merupakan sistem hukum non-statutair yang diciptakan oleh Scnouck Hugronje pada masa Pemerintahan Kolonial Hindia Belanda di Indonesia sebagai suatu hukum kebiasaan dan sebagian kecilnya adalah hukum Islam. Hukum Adat meliputi hukum-hukum yang berdasarkan keputusankeputusan hakim dan berisikan asas-asas hukum lingkungan, di mana ia memutuskan perkara, di mana hukum Adat beruratberakar pada kebudayaan tradisional yang bersifat lokal.
Sedangkan hukum syariat adalah seperangkat peraturan atau hukum ilahiyah yang bersumber kepada al-Quran dan al-Sunnah, serta memuat norma-norma hukum universal baik yang bersifat dimensi vertikal maupun horizontal. Term umum yang biasa disebut syariat terbentuk dari beragam produk hukum hasil pemikiran para ulama (figh), yang kemudian ditransformasikan ke dalam peraturan perundang-undangan melalui proses kodifikasi (taqnîn), hingga hukum Islam itu menjadi hukum positif. 
Kolaborasi antara kedua hukum itu mengakibatkan adanya pandangan bahwa hukum Adat merupakan hukum kebiasaan yang mempunyai akibat hukum (seinsollen), dan berbeda dengan kebiasaan-kebiaaan belaka, di mana kebiasaan yang merupakan Adat adalah perbuatan-perbuatan yang diulang-ulang dalam bentuk yang sama. Namun hukum dalam bentuk ini juga dapat dijumpai di setiap negara termasuk negara maju, dan di negara-negara Islam, dalam hukum Islam disebut "al-'urf" atau "al'âdah".

Hukum Adat di Indonesia yang ditemukan van Vollenhoven yang merupakan rekayasa politik hukum Belanda untuk melaksanakan politik devire et impera bangsa Indonesia. Bahkan dalam kehidupan bangsa Indonesia khususnya bagi warga negara yang beragama Islam telah menciptakan tata nilai yang mengatur tata kehidupan paling tidak menetapkan baik-buruk yang menjadi perintah dan larangan agama, dan kepatuhan hukum dan yurisprudensi Islam telah diserap menjadi bagian hukum positi.

Untuk mengkaji lebih komprehensif hukum Adat dan hukum Islam di Indonesia, penulis memandang bahwa banyak hasil penelitian yang sebelumnya pernah mengkaji obyek sejenis perlu dikembangkan lebih jauh. Namun demikian, dalam makalah ini penulis memandang perlu untuk menjelaskan secara ringkas tentang ambivalensi pelaksanaan hukum waris di Indonesia antara Adat dan syariat.

\section{B. Hukum Waris Adat}

Sebagai pengantar dalam pembahasan sistem hukum warisan adat terlebih dahulu dengan pembahasan sistem hukum Adat, dengan maksud agar lebih dapat difahami dengan baik sistem hukum warisan adat dalam penulisan ini. Bangsa Indonesia sebagai bangsa yang bermartabat mempunyai "budaya" berupa "adat-istiadat" yang mencerminkan dari pada kepribadian sesuatu bangsa Indonesia, selanjutnya menjadi sumber bagi sistem hukum Adat. ${ }^{1}$ Sedangkan istilah

Soerojo Wigjodipoero, Pengantar dan AsasAsas Hukum Adat (Jakarta: Gunung Agung. 1995), hlm. 13. "adat" berasal dari bahasa Arab, dan istilah ini telah hampir menjadi bahasa di semua daerah Indonesia. Adat dapat juga diartikan kebiasaan, sehingga secara sederhana hukum Adat atau Adatrecht dapat diartikan ke dalam bahasa Indonesia menjadi hukum kebiasaan.

Selain itu, A. Qodri Azizy memberikan konsepsi secara dinamis bawa hukum Adat Indonesia ini, lebih tepat disebut "hukum kebiasaan" (customary law) atau hukum yang hidup di masyarakat (living law) ${ }^{2}$, sedangkan dalam pengertian yang statis adalah kebiasaan atau Adat-istiAdat bangsa Indonesia yang telah dijadikan sebuah disiplin dan dikategorikan secara baku. Demikian juga Sorjono Soekanto juga mengatakan bahwa pada hakekatnya hukum Adat merupakan hukum kebiasaan, artinya kebiasaan-kebiasaan yang mempunyai akibat hukum (seinsollen), berbeda dengan kebiasaan-kebiaaan belaka, kebiasaan yang merupakan adat adalah perbuatan-perbuatan yang diulang-ulang dalam bentuk yang sama. ${ }^{3}$

Konsep hukum Adat di Indonesia hampir dipastikan ciptaan orang Belanda, ${ }^{4}$ yang mempunyai tujuan untuk mengadu kelangan Islam dengan kalangan nasional. ${ }^{5}$ Lebih jauh orang-orang Belanda menanamkan seakanakan hukum Adat adalah hukum milik kaum nasional, sedangkan hukum Islam milik asing. ${ }^{6}$ Oleh karena itu, Bustanul Arifin berpendapat bahwa istilah hukum Adat adalah artificial buatan atau karangan, karena buat rakyat Indonesia istilah hukum berarti syara'. Di daerah-daerah di Indonesia, seperti: Su-

2 A. Qodri Azizy, Eklektisisme Hukum Nasional Kompetisi antara Hukum Islam dan Hukum Umum (Yogyakarta: Gama Media. 2002), hlm. 110.

3 Soejono Soekamto, Pengantar Hukum Adat Indonesia (Jakarta : Rajawali. 1993), hlm. 37.

4 M. A. Jaspan, Mencari Hukum Baru Sinkretisme Hukum di Indonesia yang Membingungkan Mulyana W. Kusumah (ed) Hukum Politik dan Perubahan Sosial (Jakarta : Yayasan Lembaga Bantuan HUkum Indonesia. 1988), hlm. 240.

5 Amrullah Ahmad, et al, Prospek Hukum Islam dalam Kerangka Pembangunan Hukum Nasional di Indonesia, Sebuah Kenangan 65 Tahun Bustanul Arifin (Jakarta: Ikaha Jakarta. 1994), hlm. 6.

6 Jazumi, Legislasi Hukum Islam di Indonesia (Bandung : Citra Aditya Bakti. 2005), hlm. 249. 
matera, Bima, Sulawesi, dan Ternate, hukum berarti syara??

Akibat adanya ciptaan hukum Adat oleh orang-orang Belanda hukum Adat dan hukum Islam saling bertentangan satu sama lain, ${ }^{8}$ sedangkan dalam perkembangannya kedua hukum tersebut satu sama lain saling mengisi, bahkan dalam hukum perkawinan dan hukum wakaf, hukum Islam telah merepsi atau telah menjadi hukum adaptasi, termasuk hukum warisan, yang mulanya bagian antara laki-laki dan perempuan dengan istilah "belah ketupat" kemudian menjadi "sepikul segendongan". 9

Bahkan dalam kehidupan bangsa Indonesia khususnya bagi warga negara yang beragama Islam telah menciptakan tata nilai yang mengatur tata kehidupan paling tidak menetapkan baik-buruk yang menjadi perintah dan larangan agama, dan kepatuhan hukum dan yurisprudensi Islam telah diserap menjadi bagian hukum positif. ${ }^{10}$

Selanjutnya, atas dasar konsepsi hukum Adat seperti yang telah dipaparkan tersebut di atas, kemudian para sarjana, baik sarjana Belanda maupun Indonesia telah memberikan pengertian tentang hukum Adat, diantaranya adalah:

1. Soepomo memberikan pengertian bahwa hukum Adat adalah sebagai hukum yang tidak tertulis di dalam peraturan-peraturan legislatif (unstatutory law) yang meliputi peraturan-peraaturan hidup meskipun tidak ditetapkan oleh yang berwajib, yang ditaati dan didukung oleh rakyat berdasarkan atas keyakinan bahwasannya peraturan-peraturan tersebut mempunyai kekuatan hukum;

7 Bustanul Arifin Majalah Mimbar Hukum, Peradilan Agama di Indonesia (Jakarta No 10 Tahun ke 4 1991), hlm. 14.

8 Muhamamd Yahya Harahab, Kedudukan Janda, Duda dan Anak Angkat dalam Hukum Adat (Bandung: Citra Aditya Bakti. 1993), hlm. 60.

9 Soerojo Wignjodipuro, Pengantar dan AsasAsas Hukum Adat, (Jakarta : Gunung Agung. 1992), hlm. 35.

10 Juhaja S. Praja dkk, Hukum Isslam di Indonesia dalam Pemikiran dan Praktik (Bandung: Remaja Rosdakarya. 1991), hlm. 15.
2. M. M. Djojodigoeno, memberikan pengertian bahwa hukum Adat adalah hukum yang tidak bersumber kepada peraturanperaturan; ${ }^{11}$

3. C. Van Vollenhoven memberikan pengertian bahwa hukum Adat adalah hukum yang tidak bersumber kepada peraturanperaturan yang dibuat oleh pemerintah Hindia Belanda dahulu atau alat-alat kekuasaan lainnya yang menjadi sendinya dan diadakan sendiri oleh kekuasaan Belanda dahulu;

4. Kemudian Soekamto bahwa hukum Adat sebagai kompleks Adat-Adat yang kebanyakan tidak dikitabkan, tidak dikodifikasikan dan bersifat paksaan, mempunyai sanksi, jadi mempunyai akibat hukum; ${ }^{12}$ dan

5. Selanjutnya Hazairin juga memberikan pengertian bahwa setiap lapangan hukum mempunyai hubungan dengan kesusilaan, langsung atau tidak langsung. Demikian juga dengan hukum Adat: teristimewa disini dijumpai perhubungan dan persesuaian yang langsung antara hukum dan kesusilaan: pada akhirnya hubungan antara Hukum dan Adat, yaitu sedemikian berlangsungnya sehingga istilah buat yang disebut hukum Adat itu tidak dibutuhkan oleh rakyat biasa yang memahamkan menurut halnya sebutan "Adat" itu, atau dalam artinya sebagai (Adat) sopan santun atau dalam artinya sebagai hukum. ${ }^{13}$

Dalam pelaksanaan hukum warisan adat di Indonesia banyak dipengaruhi oleh prinsip garis kekerabatan atau keturunan, baik melalui ayah maupun melalui ibu. Bentuk kekerabatan itu ditentukan oleh prinsip keturunan (princeple decent) menurut Kuncoroningkrat ada empat prinsip pokok garis keturunann di Indonesia, yaitu:

11 M. M, Djojodigoeno, Asas-Asas Hukum Adat (Jogyakarta: Yayasan Badan Penerbit GAMA. 1958), hlm 6.

12 Soekamto, Meninjau Hukum Adat Indonesia (Jakarta : Soeroengsan. 1955), hlm. 73.

13 Hazairin, Tujuh Serangkai tentang Hukum (Jakarta: Bina Aksara. 1981), hlm. 117. 
1. Prinsip Patrilinel (Patrilineal Decent) yang menghitung hubungan kekerabatan melalui laki-laki saja, dan karena itu mengakibatkan bahwa tiap individu dalam masyarakat semua kaum kerabat ayah masuk ke dalam batas hubungan kekerabatannya, sedang kaun kerabat itu jatuh di luar batas itu;

2. Prinsip Matrilineal (Matrilineal Decent), yang menghubungkan hubungan kekerabatan melalui perempuan saja, dan karena itu mengakibatkan bahwa tiap-tiap individu dalam masyarakat semua kerabat ibu dalam batas hubungan kekerabatannya, sedang kaum kerabat ayah jatuh di luar batas itu;

3. Prinsip Bilineal (Bilineal Decent) prinsip ini juga sering disebut doble decent, yang menghitungkan hubungan kekerabatan melalui pria saja, untuk sejumlah hak dan kewajiban tetentu, dan melalui wanita saja untuk sejumlah hak dan kewajiban yang lain, dan karena mengakibatkan bahwa bagi tiap-tiap individu dalam masyarakat kadang-kadang semua kaum kekerabatan ayah masuk ke dalam batas hubungan kekerabatannya, sedangkan kaum kerabat ibu jatuh di laur batas itu, dan kadang-kadang sebaliknya; dan

4. Prinsip Bilateral (Bilateral Decent) yang menghitungkan hubungan kekerabatan melalui ayah dan ibu. ${ }^{14}$

Sedangkan Hazairin hanya ada tiga prinsip pokok garis kekerabatan, yaitu:

1. Patrilineal, yang menimbulkan kesatuankesatuan kekeluargaan yang besar-besar, seperti clan, marga, dimana setiap orang itu selalu menghubungkan dirinya hanya kepada ayahnya. Oleh karena itu, termasuk ke dalam clan ayahnya, yakni dalam sistem patrilineal murni seperti di tanah batak atau dimana setiap orang itu menghubungkan dirinya kepada ayahnya atau kepada maknya, tegantung kepada bentuk perkawinan orang tuannya itu, dan karena itu termasuk ke dalam clan

14 Kuntjaraningkrat, Beberapa Pokok Antropologi (Jakarta: Dian Rakyat. 1992), hlm. 135. ayahnya ataupun ke dalam clan ibunya yakni dalam system patrilineal yang beralih-alih, seperti di Lampung dan Rejang;

2. Matrilineal, yang juga menimbulkan kesatuan-kesatuan kekeluargaan yang besar-besar, seperti clan, suku, di mana setiap orang itu selalu menghubungkan dirinya hanya kepada maknya atau ibunya, dan karena itu termasuk ke dalam clan, suku, maknya itu; dan

3. Parental atau Bilateral, yang mungkin menimbulkan kesatuan-kesatuan kekeluargaan yang besar-besar, seperti tribe, rumpun, dimana setiap orang itu menghubungkan dirinya dalam hal keturunan baik kepada maknya maupun kepada ayahnya ${ }^{15}$.

Perbedaan antara Kuntjaraningkrat dengan Hazairin hanya terdapat pada prinsip belenial (belenial decent), menurut Hazairin prinsip kekerabatan ini tidak dikenal, meskipun menurut Kuntjaraningkrat ada, tetapi belum dilukiskan secara jelas, sehingga dalam masyarakat Indonesia boleh dikata tidak ada. Bentuk masyarakat dengan hubungan kekerabatan patrilinel, matrilineal, dan parental atau bilateral tersebut di atas, banyak dijumpai di dalam masyarakat Indonesia, seperti dalam bentuk masyarakat kekerabatan patrilineal dalam masyarakat Batak, Bali, Tanah Gayo, Timor, Ambon, dan Papua. Sedangkan bentuk masyarakat dengan hubungan kekerabatan matrilineal adalah di Minangkabau. Adapun bentuk masyarakat kekerabatan parental atau bilateral dapat dilihat di Jawa, Kalimantan, Riau, Lombok, dan lain sebagainya.

Bentuk sistem kekerabatan bilateral atau parental yang dianut di Jawa, inilah dalam perkembangan sistem kekerabatan di Indonesia, akan menjadikan muara perkembangan sistem patrilineal dan sistem matrilineal. Sistem kekerabatan maupun prinsip sistem garis keturunan sangat besar pengaruhnya terhadap bidang-bidang hukum

15 Hazairin, Tujuh Serangkai tentang Hukum. HIm. 11. 
Adat, seperti hukum perkawinan dan hukum waris.

Dengan demikian dapat dikatakan bahwa sistem hukum warisan Adat di Indonesia tidak terlepas dari pada sistem keluarga atau sistem kekerabatan yang telah penulis jelaskan di atas. Hukum warisan adat mempunyai corak tersendiri dari alam pikiran masyarakat yang tradisional dengan bentuk kekerabatan yang sistem keturunan patrilineal, matrilineal, parental atau bilateral. Dengan demikian, hukum warisan adat di Indonesia terdapat tiga sistem hukum warisan, yaitu: pertama sistem hukum warisan patrilineal, kedua sistem hukum warisan matrilineal, dan yang ketiga sistem hukum warisan parental atau bilateral.

\section{Hukum Waris Adat Bercorak Patrilineal}

Sistem hukum warisan patrilineal juga berpokok pangkal dari sistem kekerabatan sebagaimana yang telah penulis jelas di muka, berarti sistem hukum warisan patrilineal Adat bertitik tolak dari bentuk masyarakat dan sifat kekeluargaan patrilineal. Dalam masyarakat patrilinel seperti halnya pada masyarakat Batak Karo, hanya anak laki-laki yang menjadi ahli waris, karena anak perempuan di luar golongan patrilineal. ${ }^{16}$

Keadaan seperti ini dikarenakan adanya beberapa alasan yang melandasi sistem hukum warisan patrilineal sehingga keturunan laki-laki saja yang berhak mewarisi harta peninggalan pewaris yang telah meninggal dunia, sedangkan anak perempuan tidak mendapatkan harta warisan sama sekali. Adapun alasan yang memandang rendah kedudukan perempuan khususnya dalam masyarakat Batak adalah:

1. Emas kawin yang disebut "tukor" membuktikan perempuan dijual;

2. Adat lakonan (levirat) yang membuktikan bahwa perempuan diwarisi oleh saudara dari suaminya yang telah meninggal dunia;

3. Perempuan tidak mendapatkan warisan; dan

16 Djaja Sembiring Meliala, Hukum Adat Karo dalam rangka Pembentukan Hukum Nasional (Bandung: Tarsito. 1978), hlm. 54.
4. Perkataan naki-naki menunjukan perempuan ,makhluk tipuan dan lain-lain.

Namun dalam kenyataan di masyarakat patrilineal seperti di Batak Karo laki-lakilah yang mempunyai hak warisan dari kedua orang tuanya, hal ini dipengaruhi oleh faktor-faktor:

1. Silsilah kekeluargaan di dasarkan kepada laki-laki, anak perempuan tidak dianggap dapat melanjutkan silsilah, (keturunan keluarga);

2. Dalam rumah tangga istri bukan kepala keluarga, dan anak-anak menggunakan nama keluarga atau marga ayah, dan istri digolongkan ke dalam keluarga atau marga suami;

3. Dalam Adat perempuan tidak dapat mewakili orang tua atau ayahnya, sebab ia masuk anggota keluarga suaminya; dan

4. Dalam Adat kalimbubu (laki-laki) dianggap anggota keluarga sebagai orang tua atau ibu. ${ }^{17}$

Dalam perkawinan Adat patrilineal, apabila perempuan sudah kawin, ia dianggap keluar dari keluarganya dan menjadi keluarga suaminya, seperti seorang perempuan Nasution kemudian ia kawin dengan seorang laki-laki dari marga siregar, dengan adanya pemberian yang disebut tukor itu, maka perempuan Nasution itu bukan tetap disebut Nasution, tetapi berubah menjadi Siregar. Dengan demikian hanya laki-laki yang mendapat harta warisan, sebab anak perempuan sudah keluarga dari marganya, sehingga ia tidak mendapat harta warisan.

Ahli waris dan para ahli waris dalam sistem hukum Adat warisan patrilineal terdiri dari:

1. Anak laki-laki;

2. Anak angkat;

3. Ayah dan Ibu;

4. Keluarga terdekat; dan

5. Persekutuan Adat. ${ }^{18}$

Semua anak laki-laki menjadi ahli waris tentunya anak yang sah yang berhak menjadi

17 Eman Suparman, Inti Sari Hukum Waris Indonesia (Bandung: Armico. 1985), hlm. 53-54.

18 lbid. hlm. 55-56. 
ahli waris dari orang tuanya, baik harta dari hasil perkawinan maupun harta pusaka. Jumlah harta yang akan menjadi harta warisan itu sama diantara anak-anak laki-laki pewaris, misalnya apabila pewaris mempunyai tiga orang anak-laki-laki, maka bagian harta warisannya masing-masing mendapat sepertiga bagian. Namun bila pewaris tidak mempunyai anak-laki-laki, tetapi ahli warisnya hanya istri dan anak perempuan, maka harta pusaka itu bisa dipergunakan baik oleh istri dan anak perempuan selama hidupnya, setelah meningal dunia harta warisan itu kembali kepada asalnya atau kembali kepada "pengulihen".

Anak angkat dalam masyarakat patrilineal Batak Karo merupakan ahli waris yang berkedudukannya seperti halnya anak sah, akan tetapi anak angkat ini hanya menjadi ahli waris terhadap harta warisan atas harta perkawinan artinya hanya harta yang didapat dalam pekawinan atau harta bersama dari orang tua angkatnya, sedangkan untuk harta pusaka anak angkat tidak mempunyai hak harta warisan.

Untuk ayah dan ibu serta saudarasaudara kandung pewaris, ini muncul sebagai ahli waris apabila tidak ada anak kandung dan anak angkat pewaris, maka ayah, ibu dan saudara-saudara kandung pewaris menjadi ahli waris secara bersama-sama. Kemudian yang dimaksud keluarga terdekat ini, muncul sebagai ahli waris apabila tidak ada ahli waris anak kandung, anak angkat, ayah, ibu dan saudara-saudara pewaris. Selanjutnya yang terakhir adalah persekutuan Adat ini sebagai ahli waris apablia tidak ada sama sekali disebutkan di atas, maka harta warisan jatuh kepada persekutuan Adat.

Dalam perkembangannya hukum Adat partrilineal seperti hukum Adat warisan Batak Karo ini, juga mengalami perkembangan pertama adalah seperti apabila seorang suami mempunyai dua orang istri dan msing-masing istri yang pertama mempunyai dua anak laki-laki, sedangkan istri kedua mempunyai tiga orang anak laki-laki.
Pada dahulu awalnya cara pembagian dalam keadaan seperti berdasarkan istri, sehingga masing-masing dari istri setengah bagian. Akibatnya antara anak laki-laki dari istri pertama dengan anak laki-laki dari istri kedua berbeda, kalau anak laki-laki dari istri pertama masing-masing mendapat bagian $1 / 2: 2=1 / 4$ bagian. Sedangkan anak laki-laki dari istri ketiga karena anaknya tiga, maka bagiannya masing-masing adalah 1/2: 3=1/6 bagian.

Kemudian setelah adanya musyawarah kepala-kepala Adat Tanah Karo cara pembagian seperti di atas, dirubah tidak berdasarkan istri, tetapi bedasarkan jumlah anakanak, sehingga bila seperti contoh tersebut di atas, masing-masing anak laki-laki akan mendapat bagian sama yaitu $1 / 5$ bagian.

Selanjutnya perkembangan ini melalui putusan Mahkmahah Agung RI, tanggal 1 Nopember 1961, Nomor: 179.K/Sip/1961, dalam putusan itu terjadi upaya persamaan hak antara laki-laki dengan perempuan, meskipun putusan Mahkmah Agung tersebut ternyata disana-sini juga mendapat perdebatan diantara para ahli hukum Adat.

\section{Hukum Waris Adat Bercorak Matrilineal}

Sistem hukum warisan atas dasar kekerabatan ini, sudah berlaku sejak dahulu kala, sebelum masuknya ajaran-ajaran agama di Indonesia, seperti agama Hindu, Islam dan Kristen ${ }^{19}$, sistem ini berlaku pada hukum Adat Minangkabau, Enggano dan Timor. Meskipun dalam perkembangannya sekarang Nampak bertambah karena pengaruh sistem hukum warisan parental, disebabkan oleh surutnya kekuasan kerabat dalam hal yang menyangkut kebendaan dan pewarisan. Selain itu menurut penulis juga karena pengaruh hukum warisan Islam, karena dalam hukum Islam melaksanakan hukum warisan itu, merupakan bagian dari ibadah.

19 H. Hilman Hadikusuma, Hukum Waris Adat (Bandung: Citra Aditya Bakti. 1993), hlm. 23. 
Sistem hukum warisan matrilineal selain berhubungan dengan sistem kekerabatan, juga selalu berhubungan dengan bentukbentuk hukum perkawinannya. Dalam Adat matrilineal Minangkabau bentuk perkawinannya menurut Hazairin bentuk perkawinan yang bertahab satu sama lain, yaitu: pertama "perkawinan bertandang", kemudian kedua "perkawinan manetap", dan selanjutnya ketiga "perkawinan bebas".

1. Perkawinan Bertandang

Perkawinan bertandang juga disebut perkawinan semendo, yaitu perkawinan didasarkan kepada prinsip eksogami, yaitu suatu perkawinan dimana seorang harus kawain dengan anggota klan yang lain, atau seseorang dilarang kawin dengan anggota $\mathrm{klan}^{21}$. Dan perkawinan mempunyai hubungan yang erat dengan sistem garis keturunan ibu. Sedangkan semenda berarti lakilaki dari luar yang didatangkan ketempat perempuan. Dengan demikian suami adalah semata-mata orang yang datang bertamu "datang malam hilang pagi esoknya" ia berhak atas anak, tetapi tidak berhak yang berhubungan harta dan dalam rumah tangganya. Sehingga dalam bentuk perkawinan seperti tidak ada harta bersama antara suami dan istri, demikian pula juga tidak ada hak warisan suami dari harta di dalam suami istri tersebut.

Dalam bentuk perkawinan dalam sistem hukum warisan adat Minangkabau ini, Amir Syarifuddin telah mengadakan penelitian dalam desertasinya yang berjudul Pelaksanaan Hukum Kewarisan Islam dalam Lingkungan Adat Minangkabau, di mana dalam hasil penelitiannya menerangkan bahwa "Adat Minangkabau mempunyai pengertian tersendiri tentang keluarga dan tata cara perkawinan, kemudian menimbulkan bentuk atau asas tersendiri dalam hukum warisan". ${ }^{22}$

20 Hazairin, Pergolakan, Penyesuaian Adat kepada Hukum Islam (Jakarta: Bulan Bintang. 1952), hlm 15.

21 Bushar Muhammad, Pokok-Pokok Hukum Adat (Jakarta: Pradnya Paramita. 1981), hlm. 10.

22 Amir Syarifuddin, Pelaksanaan Hukum Kewarisan Islam dalam Adat Minangkabau (Jakarta: Gunung Agung. 1982), hlm. 256

\section{Perkawinan Menetap}

Perkawinan menetap merupakan bentuk perkawinan tahab kedua yang merupakan perkembangan dari bentuk perkawinan bertandang. Hal ini biasanya dikarenakan kalau rumah-rumah gadang sudah menjadi sempit, sedangkan keluarga bertambang tumbuh berkembang, maka atas inisiatif dari pihak istri membuat rumah lain yang terpisah, (biasanya tidak jauh dari rumah gadang yang dihuni beberapa suamiistri). Meskipun belum hilang sifat eksogami semendonya, akan tetapi secara fisik mereka berdua sudah pisah dengan kerabat jalur istri, dengan suasana baru, lebih bebas, lebih intim apalagi mereka mepunyai pekerjaan dan penghasilan sendiri. Dan suami lebih banyak tinggal bersama keluarganya maka menetaplah mereka di luar rumah gadang.

3. Perkawinan Bebas

Tahab berikutnya sebagai kelanjutan dari perkawinan menatap ialah berkawinan bebas, ini berarti perpindahan secara pisik, meninggalkan rumah gadang, meninggalkan desa dan pergi ke kota, bahkan mungkin meninggalkan kampung halaman.

Secara sosiologis dengan berpindahnya suami-istri ke tempat lain secara merantau atau migration itu merupakan suatu faktor yang kuat dalam perubahan sosial atau pergeseran sosial, baik secara individu maupun secara kelompok. Akibat dari pada pergeseran atau perubahan sosial itu dapat menimbulkan pelepasan Adat atau ikatan kelompok bahkan ikatan klan dan juga pelepasan harta pusaka.

Setelah terlepas dari ikatan-ikatan klan dan tunduk pada peraturan-peraturan Adat Minangkabau, baik tertulis atau tidak, suami istri yang demikian atau suasana demikian apalagi di tempat perantauan berpenghasilan sendiri, tanpa adanya bantuan dari kampung asalnya. Sehingga bertambah jauhlah dan bertambah bebas mereka terhadap harta pusaka yang berupa sawah, kebun rumah di kampung halamannya. 
Selanjutnya suami istri yang telah membentuk rumah tangga ini lambat laun menjurus membentuk kehidupan keluarga keibu-bapakan atau sistem parental atau bilateral. Bentuk ini menunjukan pula adanya suatu pergeseran pola yang evolonistis dari sistem matrilinel kepada sistem parental atau bilateral yang juga merupakan suatu kehidupan modern ${ }^{23}$. Di samping tersebut di atas, akibat dari pergeseran ini, hukum warisan tentunya juga mulai bergeser yang tadinya seorang suami dari Minangkabau tidak mempunyai hak atas harta, kemudian dengan bentuk perkawinan bebas menjadi mempunyai hak harta dalam dalam rumah tangga.

Selain itu, pengertian tentang harta dan kegunaannya menurut Adat Minangkabau, pertama harta pusaka adalah milik kaum dan dipergunakan hanya untuk kepentingan kaum secara kolektif ${ }^{24}$. Sehingga pembagian harta warisan kepada garis laki-laki berarti mengalihkan harta keluar kaum. Kedua adalah "asas kolektif", asas ini dimaksudkan bahwa dalam penerimaan harta pusaka bekanlah orang-perorang, tetapi satu kelompok secara bersama-sama atas dasar asas ini, maka harta tidak dibagi-bagi dan harus disampaikan kepada kelompok dalam bentuk kesatuan yang tak terbagi. ${ }^{25}$ Sedangkan yang ketiga "asas keutamaan", asas ini ialah bahwa penerimaan harta pusaka, atau seorang yang mempunyai peranan penerimaan harta pusaka. Dalam Adat Minangkabau ada tingkatan-tingkatan hak yang menyebabkan satu pihak lebih berhak dibandingkan dengan pihak yang lain, dan selama yang lebih berhak masih ada, maka yang lain belum mempunyai hak.

Sistem keutamaan ini, sebenarnya tidak dalam sistem penerimaan harta pusaka Adat Minangkabau, tetapi hampir setiap sosial kemasyarakatn ada sistem keutamaan, seperti seorang yang berhak wali dalam

23 Hazairin, Tujuh Serangkai tentang Hukum. hlm. 26.

24 Ibid.

25 Ibid. perkawinan, penerima zakat dan lain sebagainya. Namun dalam Adat Minangkabau mempunyai bentuk tersendiri yang disebabkan karena bentuk-bentuk lapisan-lapisan kekerabatan.

Lapisan pertama disebut "bertali darah, artinya hubungan pewaris dngan ahli waris adanya kesamaan keturunan melalui garis perempuan, lapisan kedua disebut " bertali Adat" adalah secara Adat hubungan pewaris dengan ahli waris tidak diketahui bertali Adat, tetapi secara Adat diketahui keduanya dinyatakan mempunyai hubungan kerabat karena sukunya sama, hanya berbeda negeri, sedangkan lapisan ketiga ketiga disebut" bertali budi" artinya hubungan antara pewaris dengan ahli waris tidak diikat dengan hubungan darah dan hubungan kesamaan suku, tetapi kelompok di luar suku menempatkan dirinya di satu suku atau kerabat, dan berbuat jasa pada suku tersebut. Selanjutnya lapisan keempat disebut "bertali emas" ini terjadi yang tidak sedarah dan tidak sesuku, tetapi datang menyandar kepada suatu suku atau kaum untuk ikut mengusahakan tanah ulayat itu, Selanjutnya mereka untuk dapat diterima sebagai kerabat ia diwajibkan mengisi/menyerahkan sesuatu Adat dalam bentuk emas.

Dasar pewarisan dalam Adat matrilineal Minangkabau dalam hal ahli waris dinyatakan dalam pepatah Adat yang mengatakan :

Birik-birik turun ke semah

tibah disemah berilah makan

Harta ninik turun ke mamak

dari mamak turun ke kemenakan.

Berdasarkan pepatah Adat, yang merupakan hukum Adat tersebut, menunjukan bahwa harta ninik turun ke mamak dan mamak turun ke kemenakan, berarti harta warisan yang merupakan harta pusaka turun golongan perempuan (ninik, mamak dan kemenakan), dan pengertian ninik, mamak, dan kemenakan itu tidak boleh dipahami orang-perorang, tetapi harus dipahami sebagai kelompok atau generasi. 
Sedangkan harta warisan yang bukan harta pusaka atau harta suarang tidaklah demikian. Karena harta suarang adalah harta bersama antara suami istri, di mana harta tersebut didapat oleh suami dan istri selama perkawinan, sehingga apabila salah satu meninggal dunia baik suami maupun istri, maka suami atau istri akan mendapat $1 / 2$ (setengah) dari harta suarang tersebut. Dengan demikian anak-anak dari suami istri ini, baik laki-laki maupun perempuan juga akan mendapat bagian harta warisan dari harta suarang karena mereka sebagai ahli waris.

\section{E. Hukum Waris Adat Bercorak Parental atau Bilateral}

Hukum warisan parental atau bilateral adalah memberikan hak yag sama antara pihak laki-laki dan pihak perempuan, baik kepada suami dan istri, serta anak laki-laki dan anak perempuan termasuk keluarga dari pihak laki-laki dan keluarga pihak perempuan. Ini berarti bahwa anak laki-laki dan anak perempuan adalah sama-sama mendapatkan hak warisan dari kedua orang tuanya, bahkan duda dan janda dalam perkembangannya juga termasuk saling mewarisi.

Bahkan proses pemberian harta kepada ahli waris khususnya kepada anak, baik kepada anak laki-laki maupun anak perempuan umumnya telah dimulai sebelum orang tua atau pewaris masih hidup. Dan sistem pembagian harta warisan dalam masyarakat ini adalah individual artinya bahwa harta peninggalan dapat dibagi-bagikan dari pemiliknya atau pewaris kepada para ahli warisnya, dan dimiliki secara pribadi.

Sifat sistem hukum warisan adat parental atau bilateral yang pada umumnya di pulau Jawa, termasuk Jawa Timur, Jawa Tengah, Jawa Barat dan Daerah Khusus Ibukota Jakarta, sebenarnya dapat dilihat dari beberapa segi :

1. Segi jenis kelamin, ini dapat dibagi dua kelompok, pertama kelompok laki-laki dan kelompok perempuan; dan

2. Segi hubungan antara pewaris dengan ahli waris, ini juga ada dua kelompok pertama yaitu kelompok ahli waris karena terjadinya ikatan perkawinan, yaitu suami dan istri. Kelompok kedua adalah kelompok hubungan kekerabatan, karena adanya hubungan darah ini ada tiga yaitu: kelompok keturunan pewaris, seperti anak-anak pewaris, cucu pewaris, cicit pewaris dan seterusnya ke bawah. Kelompok asal dari pada pewaris, yaitu orang tua dari pewaris, seperti ayah dan ibu dari pewaris, kakek dan nenek pewaris, buyut laki-laki dan buyut perempuan pewaris, dan seterusnya ke atas. Dan kelompok ketiga adalah hubungan kesamping dari pewaris, seperti saudarasaudara pewaris, baik laki-laki maupun perempuan seterusnya sampai anak cucunya serta paman dan bibi seterusnya sampai anak cucunya, dan siwo atau uwa laki-laki dan perempuan sampai anak cucunya.

Dalam sistem hukum warisan parental atau bilateral juga menganut keutamaan sebagai mana sistem hukum warisan matrilineal. Menurut Hazairin ada tujuh kelompok keutamaan ahli waris parental atau bilateral. Artinya ada kelompok ahli pertama, kelompok ahli waris kedua, kelompok ahli waris ketiga dan seterusnya sampai kelompok ahli waris ketujuh.

Dimaksud kelompok keutamaan disini, ialah suatu garis hukum yang menentukan di antara kelompok keluarga pewaris, yang paling berhak atas harta warisan dari pewaris, artinya kelompok pertama diutamakan dari kelompok kedua dan kelompok kedua diutamakan dari kelompok ketiga dan seterusnya ${ }^{26}$. Sehingga kelompok-kelompok ini mempunyai akibat hukum, bahwa kelompok pertama menutup kelompok kedua, dan kelompok kedua menutup kelompok ketiga seterusnya sampai kelompok ketujuh, kelompok keutamaan ahli waris itu adalah sebagai berikut:

1. Anak beserta keturunnya atau garis bawah;

2. Orang tua (ayah dan ibu) atau garis atas tahab pertama;

26 Hazairin, Hazairin, Tujuh Serangkai tentang Hukum. HIm. 17. 
3. Saudara beserta keturunannya atau garis sisi pertama;

4. Orang tua dari orang tua (simbah jumlahnya 4 orang) atau garis atas tarap kedua;

5. Saudara dari orang tua beserta keturunan dari saudara orang tua atau garis sisi kedua;

6. Orang tua dari orang tua dari orang tua (buyut jumlahnya 8 orang) atau garus atas tarap ketiga; dan

7. Saudara dari orang tua dari orang tua (saudaranya simbah) beserta keturunannya dari saudara tersebut. ${ }^{27}$

Berdasarkan uraian tersebut di atas, tampaknya hukum warisan parental itu tidak terlepas dari sistem kekerbatan yang berlaku, karena kelompok ahli waris itu menghitungkan hubungan kekerabatan malalui jalur laki-laki dan jalur perempuan. Sehingga kedudukan ahli waris laki-laki dan perempuan sama sebagai ahli waris.

\section{F. Hukum Waris Adat Versus Hukum Waris Islam}

Adanya variasi itu karena terpengaruh ajaran agama Islam, karena hukum warisan Islam perolehan harta warisan antara lakilaki dengan perempuan dua berbanding satu, artinya laki-laki mendapat dua bagian, sedangkan perempuan mendapat satu bagian, (lihat al-Quran Surat al-Nisâ' ayat 11 dan 12).

Dengan adanya perubahan perolehan harta warisan antara laki-laki dengan perempuan, ini membuktikan bahwa hukum warisan adat parental khususnya di Jawa telah mendapat resepsi dari hukum Islam, meskipun dalam praktik belum seluruhnya mayarakat merecepsi hukum warisan Islam. Hal ini dikarenakan umat Islam di Jawa khususnya di pedalaman Islam dikembangkan dengan tafsir sifustik yang mementingkan hakekat dari pada syariat yang kemudian membentuk budaya kebatinan atau sering disebut "kejawen"28. Dengan demikian me-

27 Ibid.

28 Budaya kebatinan atau kejawen adalah salah satu rekayasa struktural pembauran antara Islam dan tradisi lama, Hindu dan budha, dalam nurut $H$. Simuh bahwa umat Islam di pedalaman Jawa meskipun sejak abat ke 13 telah beragama Islam, tetapi masih mendukung nilai-nilai budaya lama (animisme dan Hinduisme).

Di samping itu tentunya dakwah Islam berhubungan dengan hukum-hukum keluarga, khususnya hukum warisan belum optimal dilakukan oleh para jura dakwah, sehingga pengetahuan hukum warisan belum dipahami betul oleh umat Islam di daerah pedalaman. Hal ini juga dapat diperhatikan bahwa penyampain ajaran Islam lebih banyak mengenai ibadah mahdloh, kebanyakan yang berkaitan shalat, puasa, haji dan lain sebagainya.

Sementara itu pemerintah Hindia Belanda telah mejajah Indonesia kurang lebih selama 350 tahun, sehingga tidak mungkin mereka tidak membawa sistem hukumnya untuk diberlakukan di Indonesia. Sistem hukum yang diberlakukan adalah adalah sistem hukum kontinental yang telah diterangkan di muka, bahwa untuk sistem hukum perdata, khususnya hukum warisan yang telah dikodifikasikan, yaitu Burgerlijk Wetboek yang disingkat BW.

Hukum Perdata Barat (BW) meskipun tidak sesuai dengan kondisi negara Indonesia, namun untuk menghindari kekosongan hukum bagi warga negara keturunan asing, tetap diberlakukan, meskipun Dewan Perwakilan Rakyat RI dan pemerintah telah menyadarinya, tetapi belum merubah dan membuat hukum warisan Indonesia seperti hukum perkawinan dalam Undang-Undang Nomor 1 Tahun 1974. Dalam BW tersebut, ada dua macam cara untuk mendapatkan harta warisan pertama berdasarkan kententuan undang-undang atau disebut " $a b$

\footnotetext{
lingkungan tradisi pedalaman Jawa pada umumnya di lingkungan di Kraton Jawa, namun selain itu juga terdapat corak mistik yang murni Islam yang disebut "tasawwuf". Kehidupan tasawwuf ini lebih menekankan dan mementingkan dimensi batin dari pada dimensi lahir. Lain halnya dengan daerah pesisir pada umumnya menekankan kepada prilaku syari'ah secara ketat.
} 
intestate", dan kedua berdasarkan "testament" atau "wasiat".

Hukum Warisan Perdata Barat (BW), mulanya hanya diberlakukan kepada orangorang Belanda dan orang-orang Eropa yang berada di Indonesia, kemudian diperluas orang-orang asing kecuali orang-orang Arab yang beragama Islam. Jadi hukum warisan perdata BW berlaku kepada orang-orang keturunan asing yang tidak beragama Islam, seperti orang-orang China, Tailand, Jepang, dan lain-lain. Sedangkan orang asli Indonesia selain yang beragam Islam berlaku hukum Adat yang telah dijelaskan di muka. Adapun yang beragama Islam berlaku hukum warisan Islam.

Sementara itu ada seperangkat asasasas hukum warisan Islam dalam teks alQuran dan al-Sunnah tidak dijumpai, dan asas tersebut merupakan hasil ijtihad para mujtahid atau ahli hukum Islam. Dengan demikian kemungkinan asas hukum warisan Islam itu beragam. Menurut Amir Syarifuddin asas hukum warisan Islam lima macam, yaitu (1) asas ijbari, (2) asas bilateral, (3) asas individual, (4) asas keadilan berimbang, dan (5) asas warisan semata akibat kematian. ${ }^{29}$

1. Asas ljbari

Kata ijbari secara etimologi mengandung arti paksaan, artinya melakukan sesuatu diluar kehendaknya sendiri3 ${ }^{30}$ Karena hukum warisan Islam berasaskan ijbari, maka pelaksanaan pembagian harta warisan itu mengandung arti paksaan tidak kehendak pewaris sebagaimana hukum warisan perdata barat. Kemudian Amir Syarifuddin ${ }^{31}$ pengertian asas ijbari itu mengandung beberpa segi.

Pertama, segi peralihan harta, artinya dengan meninggal dunianya seseorang dengan sedirinya harta peninggalannya beralih kepada orang lain dalam hal ini ahli warisnya. Menurut asas ini, pewaris dan ahli waris tidak diperbolehkan meren-

29 Amir Syarifuddin, Pelaksanaan Hukum Kewarisan Islam. hlm. 18.

30 Ibid.

31 Ibid. canakan peralihan harta peninggalan pewaris;

Kedua, segi jumlah harta artinya jumlah atau bagian ahli waris dari harta peninggalan orang yang meninggal dunia (pewaris) itu sudah ditentukan oleh ketentuan-ketenatuan Allah SWT, dan Sunnah Rasulullah SAW. Sehingga pewaris dan ahli tidak diperbolehkan menentukan jumlah bagin-bagiannya; dan

Ketiga, segi kepada siapa harta itu beralih, artinya orang-orang (ahli waris) yang menerima peralihan harta peninggalan pewaris itu sudah ditetapkan oleh alQuran dan al-Sunnah Rasulullah SAW, sehingga pewaris maupun ahli waris tidak diperbolehkan merubahnya.

2. Asas Individual

Maksud dari pada asas ini adalah harta warisan dari pewaris yang telah diterima oleh ahli warisnya, dapat dimiliki secara individu perorangan. Jadi bagian-bagian setiap ahli waris tidak terikat dengan ahli waris lainnya, tidak seperti dalam hukum Adat ada bagian yang sifatnya tidak dapat dimiliki secara pweroranga, tetapi dimiliki secara kelompok.

3. Asas Bilateral

4. Asas bilateral artinya ahli waris menerima harta warisan dari garis keturunan atau kerabat dari pihak laki-laki dan pihak perempuan, demikian sebaliknya peralihan harta peninggalan dari pihak garis keturunan pewaris laki-laki maupun perempuan.

5. Asas Keadilan Berimbang

Dari pihak laki-laki dan pihak perempuan menerima harta warisan secara berimbang artinya dari garis keturunan pihak laki-laki dan darl garis keturunan pihak perempuan menerima harta warisan sesuai dengan keseimbangan tanggung jawab dalam kehidupan rumah tangga.

Antara laki-laki dengan perempuan keduanya mempunyai hak menerima harta warisan dari pewaris, namun tanggung jawab antara laki-laki dengan perempuan berbeda, laki-laki (public family) sebagai kepala rumah tangga bertanggung jawab 
nafkah keluarganya, sedangkan perempuan sebagai ibu rumah tangga (domistic family), yang mengatur rumah tangga. Dengan demikian sewajarnya kalau alQuran menetapkan laki-laki mendapat dua bagian sedangkan perempuan satu bagian.

6. Asas Warisan Semata Kematian

Hukum warisan Islam hanya mengenal satu bentuk warisan karena adanya kematian, seperti dalam hukum warisan perdata barat (BW), dengan istlah "ab intestato", namun dalam hukum warisan BW, selain ab intestato juga karena adanya "wasiat" yang disebut "testament" termasuk sebagai bagian dari hukum warisan. Lain halnya dangan hukum Islam wasiat suatu lembaga hukum tersendiri, bukan sebagai bagian hukum warisan.

Menurut Amir Syarifuddin, asas ini ada hubungannya sangat erat dengan asas ijbari, $^{32}$ disebabkan meskipun seorang ada kebebasan atas hartanya, tetapi setelah meninggal dunia kebebasan itu tidak ada lagi. Hal ini juga difahami bahwa harta dalam Islam mempunyai sifat amanah (titipan), artinya manusia berhak mengatur, tetapi harus sesuai dengan ketetapan-ketetapan Allah SWT, sehingga apabila seorang telah meninggal dunia tidak mempunyai hak lagi untuk mengaturnya, dan kembali kepadaNya.

Di samping itu, dalam hukum warisan Islam sama dengan hukum warisan adat terdapat unsur-unsur yang dalam hukum Islam disebut rukun. Adapun unsur-unsur hukum warisan Islam, antara lain: Pertama, pewaris (muwaris), yaitu orang yang telah meninggal dunia dan meninggalkan harta warisan; dan kedua, harta warisan adalah harta, baik berupa harta bergerak, tidak bergerak, dan harta yang tidak maujud, seperti hak intelektual, hak cipta dan lain-lain.

Keberadaan harta tersebut dapat dibagikan kepada para ahli waris, setelah dikurangi biaya-biaya perawatan/pengobatan pewaris, pemakaman, pembayaran hutang,

32 Ibid. hlm. 35 . dan wasiat. Sedangkan unsur yang terakhir adalah ahli waris yaitu orang yang berhak menerima harta warisan. Pendek kata, harta warisan dapat dibagikan jika semua kewajiban muwaris telah selesai ditunaikan.

\section{Pewaris}

Pewaris ialah seorang yang telah meninggal dunia dan meninggalkan sesuatu yang dapat beralih kepada keluarganya yang masih hidup ${ }^{33}$. Sedangkan apabila seseorang yang meninggal dunia itu tidak meninggalkan sesuatu yang dapat beralih kepada keluarganya yang masih hidup ia bukan pewaris. Dalam hukum warisan Islam, yang menjadi faktor-faktor warisan adalah karena hubungan nasab, karena hubungan perkawinan dank arena hubungan wala' atau budak.

Kemudian dalam hukum Islam Amir Syarifuddin mengatakan bahwa pewaris dalam kelompok pengertian "walidani" sebagaimana ketentuan surat al-Nisâ' ayat 7 dan 33 adalah ayah, ibu, kakek nenek, anak dan cucu. Sedangkan pewaris dalam kelompok pengertian "aqrabuna", sebagaimana ditemukan dalam surat al-Nisâ' ayat 12 dan 176 adalah suami dan istri dan saudara. ${ }^{34}$ Kemudian pengertian menurut al-Quran diperluas dengan Hadits Nabi saw, dengan memasukan keturunan ayah dan keturunan kakek, sehingga termasuk anak saudara dan paman serta bibij ${ }^{35}$, kemudian pewaris karena telah memerdekakan budak (wala') yang tidak meninggalkan ahli waris.

Pada uraian sebelumnya, penulis telah dijelaskan bahwa atas dasar prinsip meninggalnya seseorang itu, berlakunya pembagian harta warisan, sehingga pewaris itu harus nyata meninggal dunia. Kemudian ada dua bentuk meninggal dunia: pertama, seseorang meninggal dunia, artinya seseorang telah nyata putusnya nyawa dari jasad yang dibuktikan dengan pancaidera atau melalui

\footnotetext{
Ibid. 51.

lbid. hlm. 52.

35 lbid.
} 
medis atau tidak hidup lagi. ${ }^{36}$ Kedua, dianggap meninggal dunia secara hukum, meninggal dunia adalah meninggal dunia karena putusan pengadilan, artinya seseorang dianggap atau dinyatakan meninggal dunia dengan putusan hakim, kemungkinan orang tersebut masih hidup tetapi disebabkan oleh sesuatu hal tertentu orang itu dianggap meninggal dunia, seperti dalam kasus seorang pewaris telah hilang bertahun-tahun tidak diketahui tempat tinggalnya. Hilangnya orang ini disebabkan adanya sesuatu peristiwa, seperti adanya perang, tsunami dan lain-lain.

Kemudian para ahli warisnya mengajukan ke pengadilan agar pewaris yang hilang itu diputus telah meninggal dunia, sehingga dengan putusan Pengadilan itu harta warisan pewaris dapat dibagi kepada para ahli warisnya, meskipun dimungkinkan sebenarnya seorang yang diputus sebagai pewaris itu masih hidup, dan berlakunya pelaksanaan pembagian harta warisan itu sejak hari dan tanggal putusan pengadilan tersebut.

Putusan Pengadilan tentang meninggal dunianya seseorang itu penting, bagi kepastian hukum warisan, karena salah satu tujuan dari pada hukum adalah untuk mencari kepastian hukum. Sedangkan apabila tidak ada putusan hakim akan menjadikan ketidakpastian kedudukan dari pada harta warisan dari pewaris itu. Apalagi dalam hukum Islam salah satu azas hukum warisan adalah asas ijbari artinya dengan kematian seseorang dengan sendirinya harta warisan itu berpindah kepada para ahli warisnya.

Kemudian perincian pewaris dalam hukum warisan islam dapat dilihat dalam ayat-ayat al-Quran dan Sunnah Rasulullah SAW, serta dikembangkan dengan ijtihad, maka dalam hal ini Amir Syarifuddin memberikan perincian pewaris menjadi 4 kelompok, yaitu:

a) Kelompok ayah dan ibu dan dikembangkan kakek dan nenek terus ke atas;

36 Hasan Alwi dkk, Kamus Besar Bahasa Indonesia (Jakarta: Balai Pustaka. 2001), hlm. 723. b) Kelompok anak baik anak laki-laki dan anak perempuan dan dikembangkan kepada cucu terus ke bawah;

c) Kelompok suami dan istri; dan

d) Kelompok saudara dan paman. Kelompok ini merupakan perluasan pengertian pewaris menurut al-Quran yang diperluas oleh hadist Nabi Muhammad SAW, dengan memasukan keturunan ayah dan keturunan kakek, sehingga dapat difahami bahwa seseorang dapat menjadi pewaris itu termasuk anak saudara, dan pewaris bagi pamannya. ${ }^{37}$

2. Harta Warisan

Harta adalah barang (uang dan sebagainya) yang menjadi kekayaan, ${ }^{38}$ sedangkan harta warisan adalah barang atau benda yang ditinggalkan oleh orang yang meninggal dunia yang menjadi hak ahli waris, setelah dikurangi untuk kepentingan biaya perawatan jenasah, hutang-hutang dan wasiat ${ }^{39}$. Dalam pengertian ini antara harta peninggalan dengan harta warisan dapat dibedakan. Harta peninggalan seluruh barang atau benda yang ditinggalkan oleh seseorang telah meninggal dunia, dalam arti barang tersebut milik orang pada saat meninggal dunia, sedangkan harta warisan ialah harta yang berupa barang atau benda yang berhak diterima oleh ahli waris.

Harta sebelum menjadi harta warisan dapat ditinjau dari beberapa segi ekonomi dan segi hukum ${ }^{40}$. Tinjauan segi ekonomi menitik beratkan kepada nilai kegunaan dari pada harta itu sendiri, seperti harta itu digunakan sebagai modal, untuk membeli alat rumah tangga dan lain sebagainya. Bila ditinjau dari ekonomi harta itu mempunyai karakteristik ekonomi, yang mempunyai seifat-sifat, yaitu:

a) Dapat memuaskan kebutuhan manusia;

37 Amir Syarifuddin, Pelaksanaan Hukum Kewarisan Islam. hlm. 29.

Hasan Alwi dkk, Kamus Besar Bahasa Indonesia. hlm. 390.

39 Fatchurahman, Ilmu Waris (Bandung: AlMa'arif. 1981), hlm. 36.

40 Abdul Kadir Muhammad, Hukum Harta Kekayaan (Bandung: Citra Adytia Bakti. 1994), hlm. 9. 
b) Jumlahnya relatif kurang (jadi persediaan tidak melebihi permintaan);

c) Mempunyai nilai spesifik;

d) Hanya bisa diperoleh melalui pengorbanan, diantaranya seperti kerja; dan

e) Dapat dialihkan dari seorang ke orang lain. ${ }^{41}$

Dengan karakteristik ekonomi ini, maka harta dapat dijadikan modal usaha sebagai aktivitas ekonomi, baik benda modal dari harta maupun usaha dari modal dan aktivitasnya satu sama lain tidak bisa dipisahkan, keduanya untuk mencari keuntungan, mungkin keuntunganya berupa laba, piutang atau hutang, dan bahkan mungkin akan mengalami kerugian dalam arti susut, berkurang atau hilang.

Kemudian dari segi hukum menitik beratkan kepada pelaksanaan pengaturan terhadap harta. Misalnya, status harta itu, kepemilikannya, dan tata cara mendapatkannya serta aspek lainnya. Di antara kedua segi ini, satu sama lain selalu berkaitan, seperti: harta-harta yang berbentuk modal atau bentuk lainnya cara kepindahannya diatur dengan pengaturan itu yang selanjutnya disebut "hukum", seperti hukum jual beli, hukum hibah, hukum warisaan, hukum sewa-menyewa dan lain-lainnya.

Jenis harta ada yang berwujud dan ada yang tak berwujud, yang berwujud dalam istilah ekonomi disebut "harta aktiva", harta ini dalam istilah hukum ada dua macam sifat, pertama adalah harta disebut "barang tak begerak" artinya barang tersebut tidak dapat dipindahkan, dan harta yang berupa "barang begerak" artinya harta itu dapat dipindahkan tempatnya, seperti mobil, peralatan rumah tangga dan lain sebagainya, namun dalam hukum perdata terdapat barang yang sifatnya dapat dipindahkan tempatnya, tetapi dikelompokan dalam barang tak bergerak, seperti kereta api, pesawat terbang dan kapal laut.

Harta yang berupa barang bergerak tersebut di atas, terdapat beberapa hak atas barang bergerak seperti: (a) Hak memetik

41 Ton Gunadi, Sistem Perekonomia menurut Pancasila dan Undang-Undang Dasar 1945 (Bandung: Aksara. 1981), hlm. 7. hasil atau hak memakai; (b) Hak atas uang bunga yang harus dibayar selama hidup seseorang; (c) Saham-saham dari perseroan; (d) Tanda-tanda pinjaman suatu negara baik negara sendiri maupun negara asing; dan (e) Hak menuntut ke Pengadilan tentang penyerahan barang bergerak atau pembayaran uang terhadap barang bergerak.

Dalam hukum Islam Yusif Musa yang dikutip Amir Syarifuddin dalam bukunya Pelaksanaan Hukum Kewarisan Islam dalam Lingkungan Adat Minangkabau bahwa harta kekayaan yang bukan berbentuk benda membagi hak itu kepada beberapa bentuk, yaitu:

a) Hak kebendaan yang dari segi haknya tidak dalan berupa benda, tetapi karena hubungannya yang kuat dengan harta dinilai sebagai harta, seperti hak lewat di jalan umum atau pengairan;

b) Hak kebendaan tetapi menyangkut pribadi pewaris, sseperti hak mencabut pemberian kepada orang lain;

c) Hak-hak kebendaan tetapi menyangkut dengan pribadi pewaris, seperti hak khiyar, (pilihan antara melangsungkan atau pembatalan akad); dan

d) Hak yang bukan berbentuk benda dan menyangkut pribadi seseorang, seperti hak ibu untuk menyusukan anak. ${ }^{42}$

Selanjutnya Amir Syarifuddin mengatakan bahwa ke empat macam hak tersebut di atas, para Ulama' dahulu pernah memperdebatkan, sehingga mereka menjadi perbedaan pendapat, akan tetapi perbedaan itu dapat dirumuskan sebagai berikut :

a) Hak yang oleh ulama disepakati dapat diwariskan, ialah hak-hak kebendaan yang dapat dinilai dengan harta, seperti hak melewati jalan;

b) Hak yang oleh Ulama tidak disepakati untuk diwariskan, ialah hak-hak yang bersifat pribadi, seperti hak memelihara, dan perwalian ayah terhadap anaknya; dan

c) Hak yang diperselisihkan oleh ulama, tentang tidak bilehnya menjadi harta warisan, ialah hak-hak yang tidak bersifat pribadi dan tidak pula bersifat kebenda-

42 Amir Syarifuddin, Pelaksanaan Hukum Kewarisan Islam. hlm. 56. 
an, seperti hak khiyar, dan hak pencabutan pemberian. ${ }^{43}$

Dalam hukum Islam hak kebendaan yang berbentuk hutang tidak menjadi harta warisan. Akan tetapi, harta yang menjadi hak ahli waris itu hanya harta peninggalan dalam keadaan bersih, artinya harta peninggalan itu setelah dikurangi hak-hak lain, seperti biayabiaya penguburan, pajak, zakat termasuh hutang kepada orang lain. Hutang dalam hukum Islam hutang, selain terhadap orang dan badan hukum juga hutang kepada Allah SWT. Hutang kepada Allah yaitu kewajiban materi kepada Allah yang harus ditunaikan, seperti membayar zakat, nadzar dan lain sebagainya.

Mengacu kepada pengertian tersebut di atas, bahwa harta peninggalan berbeda dengan harta warisan, harta peninggalan ialah semua harta yang ditinggalkan oleh pewaris, sedangkan harta warisan hanya harta yang berhak diterima oleh ahli waris, dimana harta harta peninggalan itu setelah dikurangi atau terlepas dari tersangkutnya segala macam hak-hak oramg lain di dalamnya.

Dengan demikian, harta peninggalan itu sebelum menjadi harta warisan dan dibagi kepada ahli warisnya harus dilakukan pelbagai tindakan pemurnian agar supaya harta yang menjadi hak orang lain tidak terpakai oleh ahli waris. Sebelum dilakukan pemurnian harus dilihat dahulu harta peninggalan tersebut, apakah harta peninggalan itu harta bersama atau harta bawaan, atau mungkin kedua harta itu menyatu di dalamnya.

Selanjutnya, jika harta bersama dan harta bawaan terpisah cara membaginya mudah, masing-masing harta itu dikuranmgi hak orang lain yang melekat di dalamnya setelah itu, dapat dibagi kepada ahli warisnya. Akan tetapi, apabila antara harta bersama dan harta bawaan itu menyatu, pertama harus dipisah dahulu antara harta bersama dengan harta bawaan, kemudian harta bersama dibagi dua, satu bagian untuk pewaris dan satu bagian untuk istri atau suaminya, lalu satu bagian dari harta bersama itu dijadikan satu atau ditambah dengan harta bawaan. Kemudian setelah di-

43 Ibid. jadikan satu antara harta bawaan dengan bagian dari harta bersama tersebut, kemudian dikurangi hak-hak orang lain melekat di dalamnya, setelah itu baru bagi kepada ahli warisnya.

\section{Ahli Waris}

Dalam hukum Islam terdapat dua paham hukum warisan, pertama hukum warisan menurut paham "ahli Sunnah wal jamaah" yang biasanya disebut "Ahli Sunni", atau "ahli sunnah" paham ini, mendasarkan pemikiran budaya Arab menganut masyarakat patrilineal. Kedua menurut paham "syi'ah", paham ini tidak mendasarkan pemikiran budaya Arab, tetapi kehendak memberikan penghargaan Fâthimah binti Muhammad dan 'Alî bin Abû Thalib, mereka adalah anak dan menantu Nabi Muhammad saw, sehingga hukum kewarisnnya bercorak bilateral atau parental. ${ }^{44}$

Dalam perkembangan hukum warisan Islam di Indonesia muncul suatu pandangan dari Hazairin dengan ijtihadnya berdasarkan kepada latar belakang keanekaragaman budaya kekerabatan Indonesia (patrilineal, matrilineal dan parental/ bilateral), menurut beliau hukum warisan yang dikehendaki alQuran dan al-Sunnah adalah sistem hukum warisan bilateral individual atau parental individual.

\section{G. Penutup}

Hukum warisan merupakan hukum yang memuat seluruh peraturan hukum yang mengatur pemindahan hak milik, barangbarang, harta benda dari generasi yang berangsur mati (yang diwariskan) kepada generasi muda (para ahli waris). Dalam banyak kasus, penerapan hukum waris pada umumnya mengacu kepada sumber hukum Adat yang asli sebelum adanya recepsi dari hukum agama. Namun ada juga yang mengacu langsung kepada ketentuan-ketentuan agama yang datang kemudian baik agama hindu maupun agama Islam.

Dalam bidang-bidang hukum Adat tersebut, para ahli hukum Adat telah me-

44 Neng Djubaedah, "Tesis Pelaksnaan Hukum Kewarisan di Kabupaten Pandeglang", Jakarta: Universitas Indinesia, hlm. 189. 
ngadakan penelitian hukum Adat menghasilkan berbagai variasi dan berusaha mengindentifikasikan bidang-bidang hukum Adat. Misalnya, dalam praktiknya ada yang menggunakan corak kekerabatan parental atau bilateral dan pula yang menerapkan corak kekerabatan patrilineal dan matrilineal. Hal ini terus berlangsung sejak zaman kedatangan Islam hingga diberlakukannya hukum waris Islam di era kemerdekaan.

Melalui tulisan ini diketahui bahwa hingga saat ini pelaksanaan hukum waris di Indonesia lebih bercirikan kombinasi antara Adat dan syariat. Hal ini tampak menjadi sikap ambivalen di kalangan masyarakat muslim, yang di satu sisi ingin menerapkan hukum waris Islam berdasarkan prinsip kewarisan menurut hukum syariat, tapi di sisi lain masih memegang teguh hukum Adat.

\section{Daftar Pustaka}

Ahmad, Amrullah. 2004. Prospek Hukum Islam dalam Kerangka Pembangunan Hukum Nasional di Indonesia, Sebuah Kenangan 65 Tahun Bustanul Arifin. Jakarta : Ikaha Jakarta.

Alwi, Hasan dkk. 2001. Kamus Besar Bahasa Indonesia. Jakarta : Balai Pustaka.

Arifin, Bustanul. 1991. Peradilan Agama di Indonesia. Jakarta: Majalah Mimbar Hukum No. 10 Tahun ke 41991.

Azizy, A. Qodri. 2002. Eklektisisme Hukum Nasional Kompetisi antara Hukum Islam dan Hukum Umum. Yogyakarta: Gama Media.

Djojodigoeno, M. M. Asas-Asas Hukum Adat. Jogyakarta. Yayasan Badan Penerbit GAMA.

Fatchurahman. 1981. Ilmu Waris. Bandung, Al-Ma'arif.

Gunadi, Ton. 1981. Sistem Perekonomian Menuirut Pancasila dan Undang-Undang Dasar 1945. Bandung: Aksara.
Hadikusuma, H. Hilman. 1993. Hukum Waris Adat. Bandung: Citra Aditya Bakti.

Harahap, Muhamamd Yahya. 1993. Kedudukan Janda, Duda dan Anak Angkat dalam Hukum Adat. Bandung: Citra Aditya Bakti.

Hazairin. 1952. Pergolakan, Penyesuaian Adat kepada Hukum Islam. Jakarta: Bulan Bintang. - 1981. Tujuh Serangkai tentang Hukum. Jakarta: Bina Aksara.

Jaspan, M. A. 1988. Mencari Hukum Baru Sinkretisme Hukum di Indonesia yang Membingungkan, Mulyana W. Kusumah (ed) Hukum Politik dan Perubahan Sosial. Jakarta: Yayasan Lembaga Bantuan Hukum Indonesia

Jazumi. 2005. Legislasi Hukum Islam di Indonesia. Bandung: Citra Aditya Bakti.

Kuntjaraningkrat. 1992. Beberapa Pokok Antropologi. Jakaarta: Dian Rakyat.

Meliala, Djaja Sembiring. 1978. Hukum Adat Karo dalam rangka Pembentukan Hukum Nasional. Bandung: Tarsito.

Muhammad, Abdul Kadir. 1994. Hukum Harta Kekayaan. Bandung: Citra Adytia Bakti.

Muhammad, Bushar. 1981. Pokok-Pokok Hukum Adat. Jakarta Pradnya Paramita.

Praja, Juhaja S. dkk. 1991. Hukum Isslam di Indonesia dalam Pemikiran dan Praktik. Bandung : Remaja Roskadakarya.

Soekamto, Soejono. 1993. Pengantar Hukum Adat Indonesia. Jakarta : Rajawali. , Soejono. 1955. Meninjau Hukum Adat Indonesia. Jakarta: Soeroengsan.

Soepomo, R. 1981. Bab-bab tentang Hukum Adat. Jakarta: Pradnya Paramita.

Suparman, Eman. 1985. Inti Sari Hukum Waris Indonesia. Bandung: Armico.

Syarifuddin, Amir. 1982. Pelaksanaan Hukum Kewarisan Islam dalam Adat Minangkabau. Jakarta : Gunung Agung.

Wigjodipoero, Soerojo. 1995. Pengantar dan Asas-Asas Hukum Adat. Jakarta: Gunung Agung. 